\title{
Physicochemical and Acid-base Properties of a Series of 2-Hydroxyethylammonium-based Protic Ionic Liquids
}

\author{
Xuedan Song, ${ }^{*}$ Ryo KAnZAKI, ${ }^{* *}$ Shin-ichi Ishiguro, ${ }^{*}$ and Yasuhiro UMEBAYASHI ${ }^{*} *$ \\ *Department of Chemistry, Faculty of Sciences, Kyushu University, 6-10-1 Hakozaki, Higashi, \\ Fukuoka 812-8581, Japan \\ **Department of Earth and Environmental Sciences, Graduate School of Science and Engineering, \\ Kagoshima University, 1-21-35 Korimoto, Kagoshima 890-0065, Japan
}

\begin{abstract}
Physicochemical properties such as a thermal behavior, ionic conductivity, viscosity and density, and acid-base properties of a new class of 2-hydroxyethylammonium-based protic ionic liquids (PILs) have been investigated. Thirty-six potential PILs were surveyed to find 32 salts with a melting point below $373 \mathrm{~K}$. Among them, $\left[(\mathrm{EtOH})_{\mathrm{n}} \mathrm{Et}_{(3-\mathrm{n})} \mathrm{NH}^{+}\right]\left[\mathrm{TFS}^{-}\right](\mathrm{Et}$, $\left.\mathrm{C}_{2} \mathrm{H}_{5} ; n=0-3\right)$ and $\left[(\mathrm{EtOH})_{2} \mathrm{EtNH}^{+}\right]\left[\mathrm{X}^{-}\right](\mathrm{X}=\mathrm{TFS}$, trifluoromethanesulfonate; TFSA, bis(trifluoromethanesulfonyl)amide; $\mathrm{NO}_{3}$ ) were studied in terms of the Walden plots, molar volume and auto-protolysis reaction for effect of the number of 2-hydroxyethyl groups introduced in the cations and for dependence of the anion nature, respectively. With regard to $\left[(\mathrm{EtOH})_{\mathrm{n}} \mathrm{Et}_{(3-\mathrm{n})} \mathrm{NH}^{+}\right]\left[\mathrm{TFS}^{-}\right](n=0-3)$, the ion-ion interactions between cation-anion and cation-cation were enhanced with increasing the number of the 2-hydroxyethyl groups. In addition, the auto-protolysis constant $K_{\mathrm{s}}$ value for $\left[(\mathrm{EtOH})_{2} \mathrm{EtNH}^{+}\right]\left[\mathrm{TFSA}^{-}\right]$is smaller than that for TFS ${ }^{-}$based PIL, indicating that HTFSA behaves as a stronger acid than HTFS in the respective PIL. On the other hand, in $\left[(\mathrm{EtOH})_{2} \mathrm{EtNH}^{+}\right]\left[\mathrm{NO}_{3}{ }^{-}\right]$, the emf jump was rather small, which suggests that the proton of $\mathrm{HNO}_{3}$ does not easily transfer to $(\mathrm{EtOH})_{2} \mathrm{EtN}$ in the liquid state.
\end{abstract}

(Received January 18, 2012; Accepted March 12, 2012; Published May 10, 2012)

\section{Introduction}

Room-temperature ionic liquids (RTILs) have been receiving much attention as new functionalized solvents in various fields of chemistry due to their unique properties. ${ }^{1-4}$ RTILs can be classified into two categories like ordinary non-aqueous solvents, i.e., aprotic (APILs) and protic (PILs) ones. PILs can be simply prepared by mixing a Brønsted acid HA and a Brønsted base B to yield $\left[\mathrm{HB}^{+}\right]\left[\mathrm{A}^{-}\right]$by proton transfer. ${ }^{5-7}$ The auto-protolysis constant $K_{\mathrm{s}}(=[\mathrm{B}][\mathrm{HA}])$ for the spontaneous auto-protolysis reaction in ionic liquids, $\mathrm{HB}^{+}+\mathrm{A}^{-} \rightleftharpoons \mathrm{B}+\mathrm{HA}$, can be a measure of the acid and base property of the $\left[\mathrm{HB}^{+}\right]\left[\mathrm{A}^{-}\right]$ ionic liquid. However, it is quite difficult to determine $K_{\mathrm{s}}$ directly because of the practical unavailability of an ordinary glass electrode in PILs. Instead, $\Delta \mathrm{p} K_{\mathrm{a}}$ has been proposed by Angell et al. ${ }^{8-10}$ which is defined as the difference between the acid dissociation constants $K_{\mathrm{a}}$ for $\mathrm{HA}$ and $\mathrm{HB}^{+}$in the respective aqueous solution. Gilbert et al. determined the Hammett acidity functions $H_{\mathrm{o}}$ of many RTILs using UV-visible spectroscopy. ${ }^{11-13}$ On the other hand, MacFarlane et al. have shown that the proton transfer of $\mathrm{HB}^{+}$to $\mathrm{A}^{-}$proceeds in the pyrrolidinium based ionic liquids (smaller $\mathrm{p} K_{\mathrm{s}}$ ), though the $\Delta \mathrm{p} K_{\mathrm{a}}$ value is 5.7 , which means significant amount of neutral species [B] and [HA] exist in equilibirium. ${ }^{14}$ Recently, we have reported the $\mathrm{p} K_{\mathrm{s}}$ value of

† To whom correspondence should be addressed.

Y. U. present address: Graduate School of Science and Technology, Niigata University, 8050 Ikarashi, 2-no-cho, Nishi, Niigata 950-2181, Japan.

E-mail: yumescc@chem.sc.niigata-u.ac.jp ethylammonium nitrate $\left[\mathrm{EtNH}_{3}{ }^{+}\right]\left[\mathrm{NO}_{3}^{-}\right]$ionic liquid by a direct potentiometry with the IS-FET (ion selective field effective transistor) and $\mathrm{Pt}\left(\mathrm{H}_{2}\right)$ electrodes. ${ }^{15,16}$ Actually, the $\mathrm{p} K_{\mathrm{s}}$ values of 10.004 with the IS-FET electrode and 9.83 with $\mathrm{Pt}\left(\mathrm{H}_{2}\right)$ one, respectively, are significantly different from the $\Delta \mathrm{p} K_{\mathrm{a}}$ value of 11.93. It is thus important to determine $\mathrm{p} K_{\mathrm{s}}$ values of ionic liquids directly.

From environmental and biological viewpoints, bio-compatible ionic liquids such as the choline-based ones of low toxicity ${ }^{17,18}$ are attracting more attention recently, because enzyme stability is improved. ${ }^{19-22}$ In addition, they act as solvents or catalysts for various organic reactions. ${ }^{23,24}$ Similarly, RTILs with the hydroxyl groups have $\mathrm{CO}_{2}$ absorption, ${ }^{25-29}$ and cellulose/protein dissolution abilities. ${ }^{30-32}$ The catalytic behavior of RTILs in the organic reactions, for instance, the yield of the product, depends on the acid-base properties of RTILs. ${ }^{33-37}$ In order to clarify solvent natures, one must have extensive knowledge of physicochemical and Brønsted and/or Lewis acid-base properties of ionic liquids. Experimental results for the physicochemical properties $^{38-52}$ and solvatochromic parameters ${ }^{53-55}$ of ionic liquids with the hydroxyl groups have been reported.

In this paper, we report a series of potential protic ionic liquids consisting of the cations with the 2-hydroxyethyl (EtOH) and/or the ethyl (Et) group shown in Fig. 1 to find new protic ionic liquids. Among them, the selected ones composed of the $(\mathrm{EtOH})_{\mathrm{n}} \mathrm{Et}_{(3-\mathrm{n})} \mathrm{NH}^{+} \quad(n=0-3) \quad$ cations coupled with trifluoromethanesulfonate $\mathrm{TFS}^{-}$, and $\left[(\mathrm{EtOH})_{2} \mathrm{EtNH}^{+}\right]$based ionic liquids combined with three anions of $\mathrm{TFS}^{-}$, bis(trifluoromethanesulfonyl)amide $\mathrm{TFSA}^{-}$and nitrate $\mathrm{NO}_{3}^{-}$ were investigated in terms of physicochemical properties such as thermal behavior, ionic conductivity, viscosity and density, 


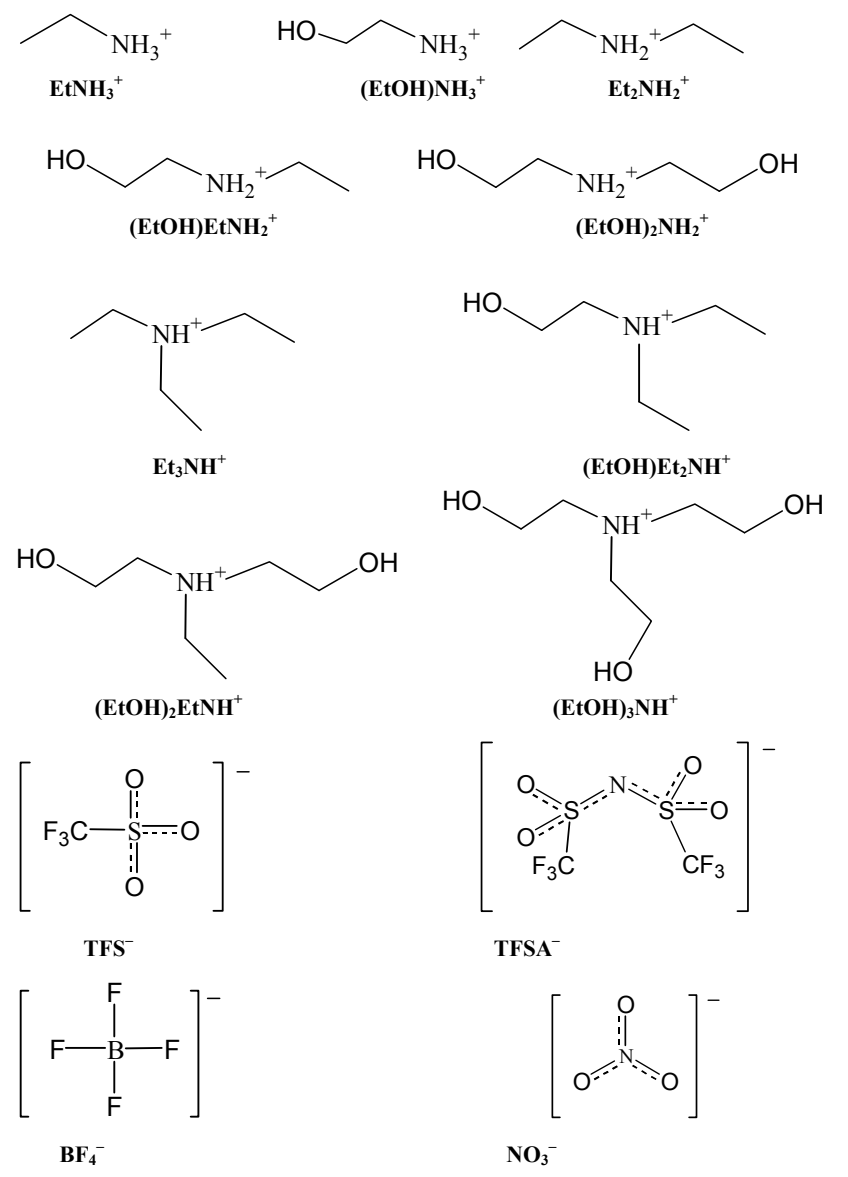

Fig. 1 Structures and abbreviations for the cations and the anions of potential protic ionic liquids (PILs) investigated in the present study.

and also the acid-base property of $\mathrm{p} K_{\mathrm{s}}$. The ion-ion interaction and the acid-base property of this new class of PILs were discussed.

\section{Experimental}

\section{Materials}

As a typical example, $\left[\mathrm{Et}_{3} \mathrm{NH}^{+}\right]\left[\mathrm{TFS}^{-}\right]$was prepared by mixing $\mathrm{Et}_{3} \mathrm{~N}$ and HTFS as follows: $\mathrm{Et}_{3} \mathrm{~N}$ was placed in a three-necked round-bottom flask immersed in an ice bath. Under vigorous stirring, HTFS was added drop wise to the amine at a temperature below $283 \mathrm{~K}$. Stirring continued for $24 \mathrm{~h}$ at the temperature to obtain a clear $\left[\mathrm{Et}_{3} \mathrm{NH}^{+}\right]\left[\mathrm{TFS}^{-}\right]$PIL. Then water and residual amine/acid were evaporated under reduced pressure for $72 \mathrm{~h}$ at room temperature. A viscous colorless or pale-yellow liquid was collected; further drying over molecular sieves $3 \mathrm{~A}$ followed. Water content in final samples was checked to be below 1000 ppm with the Karl-Fischer titration. Prepared ionic liquids were identified with the elemental analysis.

\section{Potentiometric titration}

A sample of 4-6g was set into a glass vessel with a water jacket in which the thermostating fluid was circulated. Then the temperature was elevated to melt solid salts, and the sample was thermostated at $305 \mathrm{~K}\left(\left[\mathrm{Et}_{3} \mathrm{NH}^{+}\right]\left[\mathrm{TFS}^{-}\right]\right)$and $298 \mathrm{~K}$ (others) with a temperature fluctuation of less than $0.1 \mathrm{~K}$; this was followed by adding a known amount of the corresponding base $\mathrm{B}$ to prepare an alkaline solution. $\mathrm{A} \operatorname{Pt}\left(\mathrm{H}_{2}\right)$ electrode was used,
Table 1 Screening results of potential protic ionic liquids; liquid at $298 \mathrm{~K}(\odot), 373 \mathrm{~K}(\bigcirc)$, and solid at $373 \mathrm{~K}(\bullet)$

\begin{tabular}{|c|c|c|c|c|}
\hline & TFS $^{-}$ & TFSA $^{-}$ & $\mathrm{BF}_{4}^{-}$ & $\mathrm{NO}_{3}^{-}$ \\
\hline $\mathrm{EtNH}_{3}{ }^{+}$ & $\bullet$ & 0 & 0 & () \\
\hline$(\mathrm{EtOH}) \mathrm{NH}_{3}{ }^{+}$ & 0 & 0 & () & 0 \\
\hline $\mathrm{Et}_{2} \mathrm{NH}_{2}{ }^{+}$ & $\bigcirc$ & $\bigcirc$ & $\bullet$ & $\bullet$ \\
\hline$(\mathrm{EtOH}) \mathrm{EtNH}_{2}{ }^{+}$ & $\bigcirc$ & $\bigcirc$ & (C) & (O) \\
\hline$(\mathrm{EtOH})_{2} \mathrm{NH}_{2}{ }^{+}$ & (C) & 0 & (O) & $\bigcirc$ \\
\hline $\mathrm{Et}_{3} \mathrm{NH}^{+}$ & (C) & (C) & $\bigcirc$ & - \\
\hline$(\mathrm{EtOH}) \mathrm{Et}_{2} \mathrm{NH}^{+}$ & (O) & () & () & $\bigcirc$ \\
\hline$(\mathrm{EtOH})_{2} \mathrm{EtNH}^{+}$ & (O) & (0) & (O) & (O) \\
\hline$(\mathrm{EtOH})_{3} \mathrm{NH}^{+}$ & () & (O) & $\bigcirc$ & $\bigcirc$ \\
\hline
\end{tabular}

coupled with an $\mathrm{Ag} / \mathrm{AgCl}$ reference electrode that was separated by a salt bridge with a double-junction from the sample. The cell for electromotive force (emf) measurement is represented as:

\section{$\mathrm{Ag} / \mathrm{AgCl} 0.1 \mathrm{~mol} \mathrm{dm}^{-3} \mathrm{NaCl}(\mathrm{aq}) \|$ neat sample $\|$} test sample solution $\mid \mathrm{Pt}\left(\mathrm{H}_{2}\right)$

\section{Results and Discussion}

As the first screening, a series of 36 salts were surveyed as shown in Table 1, where 4 anion species were combined with primary, secondary and tertiary ammonium cations with the 2-hydroxyethyl and/or the ethyl groups. Among them, 32 samples may solely consist of ions with a melting point below $373 \mathrm{~K}$, so that they can be classified into PILs. In addition, 17 PILs were stable liquids at an ambient temperature of $298 \mathrm{~K}$. We noticed that TFS $^{-}$and TFSA ${ }^{-}$anions gave PILs combined with all of the tertiary ammonium cations tested here, and $(\mathrm{EtOH})_{2} \mathrm{EtNH}^{+}$cation yielded PILs coupled with all anions examined in this study. Thus, with regard to 6 PILs: $\left[(\mathrm{EtOH})_{n} \mathrm{Et}_{(3-\mathrm{n})} \mathrm{NH}^{+}\right]\left[\mathrm{TFS}^{-}\right](n=0-3)$ and $\left[(\mathrm{EtOH})_{2} \mathrm{EtNH}^{+}\right]\left[\mathrm{X}^{-}\right]$ ( $\mathrm{X}=$ TFSA and $\mathrm{NO}_{3}$ ), physicochemical properties were investigated such as melting point $T_{\mathrm{m}}$, density $\rho$, ionic conductivity $\kappa$, and viscosity $\eta$. The results are listed in Table S1 (Supporting Information) accompanied by the previously reported values for analogous PILs consisting of the cations with the 2-hydroxyethyl group(s). Hence, the substitution effect of the 2-hydroxyethyl group and the anion effect can be discussed with $\left[\left(\mathrm{EtOH}_{\mathrm{n}} \mathrm{Et}_{(3-\mathrm{n})} \mathrm{NH}^{+}\right]\left[\mathrm{TFS}^{-}\right](n=\right.$ $0-3)$ and $\left[(\mathrm{EtOH})_{2} \mathrm{EtNH}^{+}\right]\left[\mathrm{X}^{-}\right]\left(\mathrm{X}=\mathrm{TFS}\right.$, TFSA and $\left.\mathrm{NO}_{3}\right)$ PILs, respectively.

To discuss the ion-ion interaction, the Walden plots of $\log (\Lambda / S$ $\left.\mathrm{cm}^{2} \mathrm{~mol}^{-1}\right) v s . \log \left(\eta^{-1} /\right.$ poise $\left.^{-1}\right)$ are useful. ${ }^{56}$ According to Angell et al..$^{8,57}$ and MacFarlane et al. ${ }^{14,58,59}$ the slope of or the deviations from the ideal Walden line could be a measure of the ion-ion interaction in ionic liquids; they generally decreased when the contact ion pair formation occurs in ordinary electrolyte solutions. The Walden plots for PILs are shown in Fig. 2 accompanied by previously reported analogous PILs of $\left[\left(\mathrm{EtOH}_{\mathrm{n}} \mathrm{Et}_{(3-\mathrm{n})} \mathrm{NH}^{+}\right]\left[\mathrm{X}^{-}\right](n=0-3)\right.$ for comparison. As shown with a dotted line in Fig. 2, the Walden plots for $\left[(\mathrm{EtOH})_{n} \mathrm{Et}_{(3-n)}\right.$ $\left.\mathrm{NH}^{+}\right]\left[\mathrm{TFS}^{-}\right](n=0-3)$ exhibited a good linear relationship with the least square slope of 0.97(5). Our finding of a linear relationship with a nearly unity slope among $\left[(\mathrm{EtOH})_{\mathrm{n}} \mathrm{Et}_{(3-\mathrm{n})^{-}}\right.$ $\left.\mathrm{NH}^{+}\right]\left[\mathrm{TFS}^{-}\right](n=0-3)$ suggests that the ion-ion interactions in these ionic liquids are similar, though the substitutions of $\mathrm{OH}$ groups increase. As is well accepted for ordinary molecular solvents, water and alcohols have greater electron pair accepting 


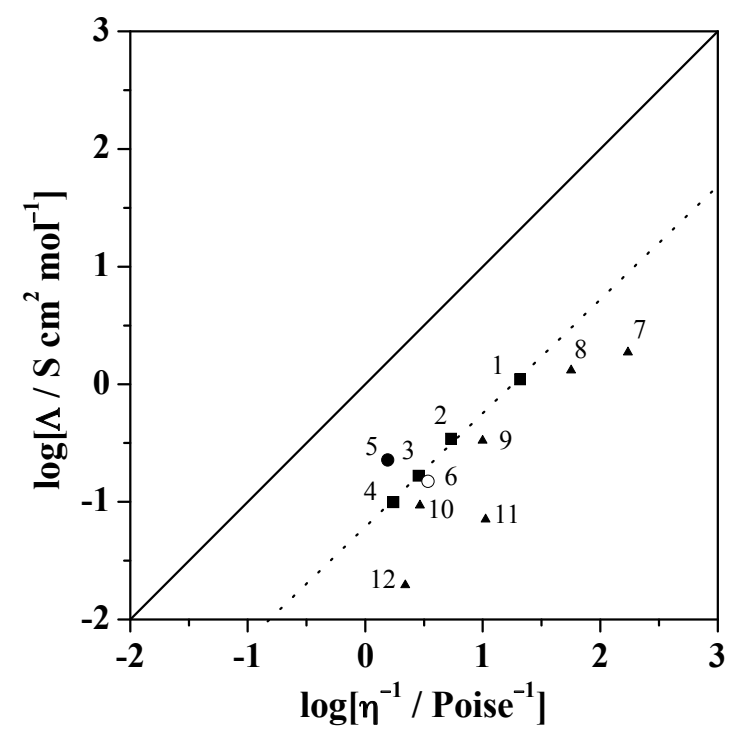

Fig. 2 The Walden plots of the examined PILs of cations with 2-hydroxyethyl groups. Solid and dotted lines show the ideal Walden line and the linear least square lines among $\left[\left(\mathrm{EtOH}_{\mathrm{n}_{\mathrm{n}}} \mathrm{Et}_{(3-\mathrm{n})} \mathrm{NH}^{+}\right][\mathrm{TFS}-]\right.$ $(n=0-3)$, respectively. The data for $\left[(\mathrm{EtOH})_{2} \mathrm{EtNH}^{+}\right]\left[\mathrm{NO}_{3}{ }^{-}\right]$is represented with open circles because of unclear ion concentrations. 1, $\left[\mathrm{Et}_{3} \mathrm{NH}^{+}\right]\left[\mathrm{TFS}^{-}\right] ; 2,\left[(\mathrm{EtOH}) \mathrm{Et}_{2} \mathrm{NH}^{+}\right]\left[\mathrm{TFS}^{-}\right] ; 3,\left[(\mathrm{EtOH})_{2} \mathrm{EtNH}^{+}\right]-$ $\left[\mathrm{TFS}^{-}\right] ; 4,\left[(\mathrm{EtOH})_{3} \mathrm{NH}^{+}\right]\left[\mathrm{TFS}^{-}\right] ; 5, \quad\left[(\mathrm{EtOH})_{2} \mathrm{EtNH}^{+}\right]\left[\mathrm{TFSA}^{-}\right] ; 6$, $\left[(\mathrm{EtOH})_{2} \mathrm{EtNH}^{+}\right]\left[\mathrm{NO}_{3}{ }^{-}\right] ; 7,\left[\mathrm{Et}_{3} \mathrm{NH}^{+}\right][$formate $]$(Ref. 42); 8, $\left[\mathrm{Et}_{3} \mathrm{NH}^{+}\right]-$ [formate] (Ref. 44); 9, [Et $\left.\mathrm{NH}^{+}\right]$[methylsulfonic acid] (Ref. 44); 10, $\left[(\mathrm{EtOH})_{3} \mathrm{NH}^{+}\right][$acetate $]$(Ref. 41); 11, $\left[\mathrm{Et}_{3} \mathrm{NH}^{+}\right][$di- $n$-butylphosphate] (Ref. 44); 12, [(EtOH) $\left.)_{3} \mathrm{NH}^{+}\right][$lactic acid] (Ref. 41).

property than the others owing to their $\mathrm{OH}$ groups, so that they are good solvents for the anions. It is supposed that the cations with the 2-hydroxyethyl group(s) have affinity with the anions owing to not only the Coulombic force but also a hydrogen bonding interaction, and their affinity should increase as the increase of the number of the 2-hydroxyethyl groups. Thus, the indication from the Walden plots seems to be inconsistent with the electron-pair accepting property, though it has been not quantitatively evaluated for the present PILs yet. In addition, quite strange behaviors in the Walden plots were recently reported for the lithium-glyme complex quasi-ionic liquids systems. ${ }^{60}$ It is worth pointing out that it is necessary to revisit the Walden plot as a measure of the ion-ion interaction.

With regard to $\left[(\mathrm{EtOH})_{2} \mathrm{EtNH}^{+}\right]\left[\mathrm{X}^{-}\right](\mathrm{X}=\mathrm{TFS}$, TFSA and $\mathrm{NO}_{3}$ ) PILs, comparison of TFS- and TFSA- is interesting. The viscosity for $\left[(\mathrm{EtOH})_{2} \mathrm{EtNH}^{+}\right]\left[\mathrm{TFSA}^{-}\right]$was noticeably larger than that for $\left[(\mathrm{EtOH})_{2} \mathrm{EtNH}^{+}\right]\left[\mathrm{TFS}^{-}\right]$. Nevertheless, ionic conductivity for $\left[(\mathrm{EtOH})_{2} \mathrm{EtNH}^{+}\right]\left[\mathrm{TFSA}^{-}\right]$was almost the same as that for $\left[(\mathrm{EtOH})_{2} \mathrm{EtNH}^{+}\right]\left[\mathrm{TFS}^{-}\right]$, and thus molar ionic conductivity for $\left[(\mathrm{EtOH})_{2} \mathrm{EtNH}^{+}\right]\left[\mathrm{TFSA}^{-}\right]$was greater. On the other hand, the TFSA--based aprotic ionic liquids coupled with 1-alkyl-3-methylimidazolium have lower melting point and viscosity and greater ionic conductivity than those in the corresponding TFS--based ones, probably due to weaker ion-ion interaction in the TFSA-based one because of wider delocalization of a negative charge around the $\left(\mathrm{SO}_{2}\right)_{2} \mathrm{~N}$ moiety. ${ }^{61}$ Therefore, as for this new class of PILs, the TFSA--based ones have a larger molar ionic conductivity probably due to more efficiently weakened ion-ion interaction, though the viscosity increases.

To obtain further insight into the ion-ion interaction in this class of PILs, we investigated molar volumes. Molar volume $V_{\mathrm{m}}$

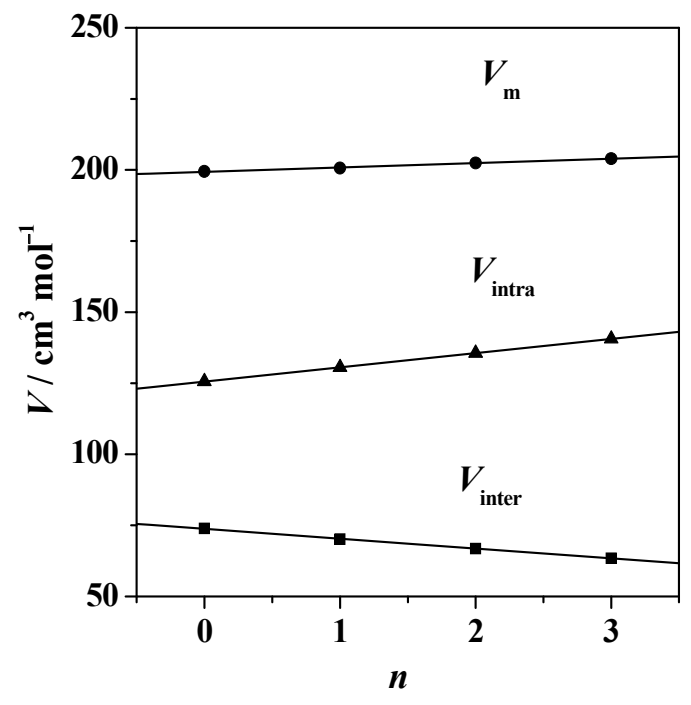

Fig. 3 The 2-hydroxyethyl group(s) number dependence of $V_{\mathrm{m}}, V_{\text {intra }}$ and $V_{\text {inter }}$ for $\left[(\mathrm{EtOH})_{n} \mathrm{Et}_{(3-n)} \mathrm{NH}^{+}\right]\left[\mathrm{TFS}^{-}\right](n=0-3)$.

at $298 \mathrm{~K}$ except $\left[\mathrm{Et}_{3} \mathrm{NH}^{+}\right]\left[\mathrm{TFS}^{-}\right]$(at $305 \mathrm{~K}$ ) was given as $V_{\mathrm{m}}=$ $M_{\mathrm{w}} / \rho$ with molecular weight $M_{\mathrm{w}}$ and density $\rho$ at the same temperature. $V_{\mathrm{m}}$ can be divided into the intra- and the intermolecular terms, i.e., $V_{\mathrm{m}}=V_{\text {intra }}+V_{\text {inter, }}$, where $V_{\text {intra }}$ and $V_{\text {inter }}$ represent the intra- and the inter-molecular molar volume, respectively. ${ }^{62}$ Figure 3 shows a dependence of $V_{\mathrm{m}}, V_{\text {intra }}$, and $V_{\text {inter }}$ on the number of the 2-hydroxyethyl groups for $\left[(\mathrm{EtOH})_{\mathrm{n}} \mathrm{Et}_{(3-\mathrm{n})} \mathrm{NH}^{+}\right]\left[\mathrm{TFS}^{-}\right](n=0-3)$. As is clearly shown in this figure, $V_{\mathrm{m}}$ and $V_{\text {intra }}$ increased, but $V_{\text {inter }}$ decreased with increasing the number of the 2-hydroxyethyl groups, suggesting the increase in $V_{\mathrm{m}}$ can be evidently attributable to that in $V_{\text {intra. }}$. Moreover, the fact of $V_{\text {inter }}$ decrease as the number of the 2-hydroxyethyl group(s) increases suggests that the liquid structuredness of these ionic liquids is enhanced by introducing the 2-hydroxyethyl groups. As mentioned above, the $\mathrm{OH}$ group has strong electron-pair accepting property, so that the increase in the number of the 2-hydroxyethyl groups may strengthen the cation-anion interaction. In addition, we can point out another possibility of the cation-cation interaction in terms of mutual hydrogen bonding against the electrostatic repulsion. Such hydrogen bonding interactions between both the cation-anion and the cation-cation were found in $\left[(\mathrm{EtOH}) \mathrm{NH}_{3}{ }^{+}\right]\left[\mathrm{NO}_{3}{ }^{-}\right]$protic ionic liquid by means of a large angle neutron scattering experiments with an empirical potential structure refinement (EPSR) analysis. ${ }^{63}$

$V_{\mathrm{m}}$ and $V_{\text {inter }}$ were plotted against $V_{\text {intra }}$ for $\left[(\mathrm{EtOH})_{\mathrm{n}} \mathrm{Et}_{(3-\mathrm{n})} \mathrm{NH}^{+}\right]-$ [TFS $\left.{ }^{-}\right](n=0-3)$ and $\left[(\mathrm{EtOH})_{2} \mathrm{EtNH}^{+}\right]\left[\mathrm{X}^{-}\right](\mathrm{X}=\mathrm{TFS}$, TFSA and $\mathrm{NO}_{3}$ ) as shown in Fig. S1 (Supporting Information). Qualitatively, linear relationships were found for both $V_{\mathrm{m}}$ and $V_{\text {inter }}$ against $V_{\text {intra }}$; the least square slopes were $1.52(3)$ and 0.52 (3) for $V_{\mathrm{m}}$ and $V_{\text {inter }}$, respectively. Similar linear relationships have been found among various APILs, ${ }^{62}$ where the least square slopes were 1.593 and 0.594 , respectively. Evidently, the smaller slope of $V_{\text {inter }}$ for the present PILs suggests that the additional hydrogen bonding interaction with the Coulombic one significantly operates among the ions in the present PILs.

\section{Acid-base property}

The auto-protolysis constant $K_{\mathrm{s}}$ can be defined as $K_{\mathrm{s}}=\left[(\mathrm{EtOH})_{\mathrm{n}} \mathrm{Et}_{(3-\mathrm{n})} \mathrm{N}\right][\mathrm{HTFS}](n=0-3)$ for the auto-protolysis reaction $(\mathrm{EtOH})_{\mathrm{n}} \mathrm{Et}_{(3-\mathrm{n})} \mathrm{NH}^{+}+\mathrm{TFS}^{-} \rightleftharpoons\left(\mathrm{EtOH}_{\mathrm{n}_{\mathrm{n}}} \mathrm{Et}_{(3-\mathrm{n})} \mathrm{N}+\mathrm{HTFS}\right.$ 


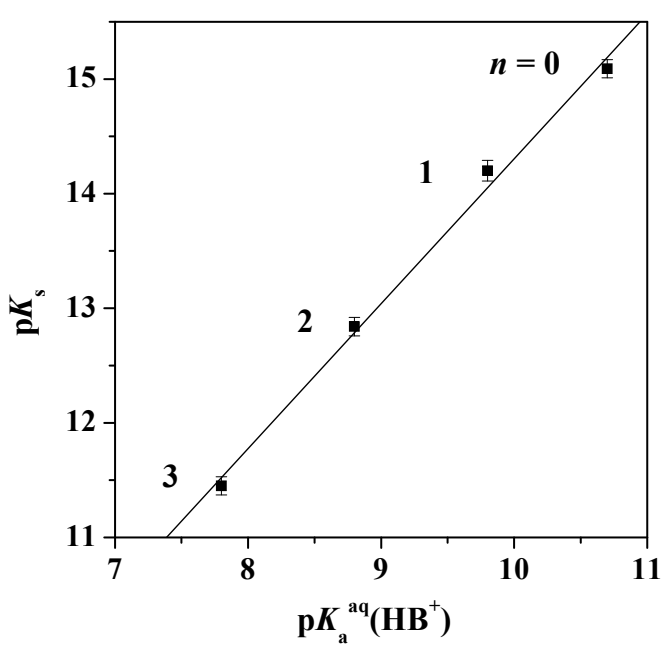

Fig. $4 \mathrm{p} K_{\mathrm{s}}$ plots $v s . \mathrm{p} K_{\mathrm{a}}$ for $(\mathrm{EtOH})_{\mathrm{n}} \mathrm{Et}_{(3-\mathrm{n})} \mathrm{NH}^{+}(n=0-3)$.

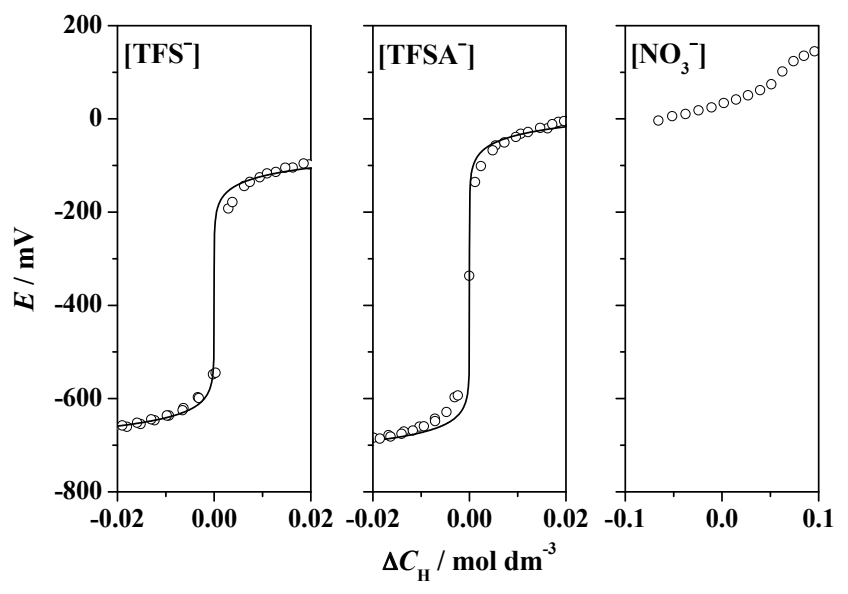

Fig. 5 Potentiometric titration curves for $\left[(\mathrm{EtOH})_{2} \mathrm{EtNH}^{+}\right]\left[\mathrm{X}^{-}\right](\mathrm{X}=$ TFS, TFSA and $\mathrm{NO}_{3}$ ). Open circles and solid lines represent experimental data and the titration curves calculated by using the refined $\mathrm{p} K_{\mathrm{s}}$ values, respectively.

in these ionic liquids. $\mathrm{p} K_{\mathrm{s}}\left(=-\log K_{\mathrm{s}}\right)$ values for $\left[(\mathrm{EtOH})_{\mathrm{n}} \mathrm{Et}_{(3-\mathrm{n})} \mathrm{NH}^{+}\right]-$ [TFS $\left.{ }^{-}\right] \quad(n=0-3)$ were successfully obtained by direct potentiometry using a $\mathrm{Pt}\left(\mathrm{H}_{2}\right)$ electrode. The values are listed in Table S1 (Supporting Information) and are plotted against acid dissociation constants $\left(\mathrm{p} K_{\mathrm{a}}\right)$ for $(\mathrm{EtOH})_{\mathrm{n}} \mathrm{Et}_{(3-\mathrm{n})} \mathrm{NH}^{+}(n=0-3)$ in the respective aqueous solution as shown in Fig. 4. Clearly, the $\mathrm{p} K_{\mathrm{s}}$ for $\left[(\mathrm{EtOH})_{\mathrm{n}} \mathrm{Et}_{(3-\mathrm{n})} \mathrm{NH}^{+}\right]\left[\mathrm{TFS}^{-}\right](n=0-3)$ linearly increased with increasing the $\mathrm{p} K_{\mathrm{a}}$. The linear relationship between $\mathrm{p} K_{\mathrm{s}}$ and $\mathrm{p} K_{\mathrm{a}}$ suggests that the acidity of the composing cation contributes to the auto-protolysis reaction in this class of PILs. Based on thermodynamic cycle, a Gibbs free energy change $\Delta_{\mathrm{r}} G^{\circ}$ (PIL) for the auto-protolysis reaction in PILs can be represented as:

$$
\begin{aligned}
\Delta_{\mathrm{r}} G^{\circ}(\mathrm{PIL})= & \Delta_{\mathrm{r}} G^{\circ}\left(\mathrm{HB}^{+}\right)-\Delta_{\mathrm{r}} G^{\circ}(\mathrm{HTFS})+\left\{\Delta_{\mathrm{t}} G^{\circ}(\mathrm{B})+\right. \\
& \left.\Delta_{\mathrm{t}} G^{\circ}(\mathrm{HTFS})\right\}-\left\{\Delta_{\mathrm{t}} G^{\circ}\left(\mathrm{HB}^{+}\right)+\Delta_{\mathrm{t}} G^{\circ}\left(\mathrm{TFS}^{-}\right)\right\},(1)
\end{aligned}
$$

where $\Delta_{\mathrm{r}} G^{\circ}\left(\mathrm{HB}^{+}\right)$and $\Delta_{\mathrm{r}} G^{\circ}(\mathrm{HTFS})$ stand for the respective acid dissociation reaction in an aqueous solution and $\Delta_{\mathrm{r}} G^{\circ}(\mathrm{X})(\mathrm{X}=$ $\mathrm{B}, \mathrm{HTFS}, \mathrm{HB}^{+}$and $\mathrm{TFS}^{-}$) denotes solvent transfer Gibbs free energy from water to the corresponding PIL for the respective species. If the solvent transfer (the third and the fourth) terms in Eq. (1) could be neglected, the linear least square slope and intercept in Fig. 4 gave unity and the acid dissociation constant for HTFS in the aqueous solution, respectively. However, the slope and the intercept were evaluated to be 1.26(6) and 1.7(6), respectively. The slope of 1.26 is significantly different from unity and the intercept of 1.7 may be too large (more positive) for that of HTFS (one of the strongest superacids), suggesting the solvent transfer free energy is never negligible.

Here, we discuss the slope of 1.26 that is significantly greater than unity. According to Eq. (1), $\Delta_{\mathrm{r}} G^{\circ}\left(\mathrm{HB}^{+}\right)$should directly depend on the 2-hydroxyethyl groups number, while $\Delta_{\mathrm{r}} G^{\circ}$ (HTFS) is to be constant. In addition, the third and the fourth terms also depend on the 2-hydroxyethyl groups number. It should be noted that transfer of the neutral species (produces in the auto-protolysis) from water to the respective ionic liquid could be more positive in Gibbs free energy than the corresponding transfer of the ionic ones (reactants), and the third term solely contributes to $\Delta_{\mathrm{r}} G^{\circ}$ (PIL) negatively. The slope of 1.26 means the negative contribution from the third term to $\Delta_{\mathrm{r}} G^{\circ}$ (PIL) may be superior to positive one from the fourth. This suggests that the hydrogen bonding interactions become more important relative to the Coulombic ones in these PILs when the number of the 2-hydroxyethyl groups increase, which is consistent with the discussion based on molar volume.

We also attempted to determine $\mathrm{p} K_{\mathrm{s}}$ for $\left[(\mathrm{EtOH})_{2} \mathrm{EtNH}^{+}\right]\left[\mathrm{X}^{-}\right]$ $\left(\mathrm{X}=\mathrm{TFS}\right.$, TFSA, and $\mathrm{NO}_{3}$ ). Typical potentiometric titration curves for these PILs are shown in Fig. 5. As shown in this figure, $\mathrm{p} K_{\mathrm{s}}$ for $\left[(\mathrm{EtOH})_{2} \mathrm{EtNH}^{+}\right]\left[\mathrm{TFS}^{-}\right]$and $\left[(\mathrm{EtOH})_{2} \mathrm{EtNH}^{+}\right]\left[\mathrm{TFSA}^{-}\right]$ were successfully evaluated to be 12.84(8) and 14.80(9), respectively, which implies that HTFSA behaves as a stronger acid than HTFS in the respective ionic liquids. As aforementioned, HTFS is one of the strongest superacids, and HTFSA may be also strong acid, though their $\mathrm{p} K_{\mathrm{a}}$ value in the respective aqueous solution and/or Hammett acid function $H_{0}$ is unclear currently. On the other hand, gas phase acidity of HTFS and HTFSA have been reported to be $1253.1 \mathrm{~kJ} \mathrm{~mol}^{-1}$ and $1198.7 \mathrm{~kJ} \mathrm{~mol}^{-1}$, respectively. ${ }^{64}$ In the gas phase, the acidity of HTFSA is noticeably stronger than HTFS. Thus, the acidity order of HTFS and HTFSA in PILs composed of $\left[(\mathrm{EtOH})_{2} \mathrm{EtNH}^{+}\right]$ are consistent with that in the gas phase. It should be noted that a significant difference in acidity between HTFS and HTFSA in the gas phase is rather suppressed in the PILs. In fact, the $\mathrm{p} K_{\mathrm{s}}$ value for $\left[\mathrm{C}_{1} \mathrm{hIm}^{+}\right]\left[\mathrm{TFS}^{-}\right]\left(\mathrm{C}_{1} \mathrm{hIm}^{+}, N\right.$-methylimidazolium $\left.)\right]$ of 8.93 is larger than that for $\left[\mathrm{C}_{1} \mathrm{hIm}^{+}\right]\left[\mathrm{TFSA}^{-}\right]$of $8.58,{ }^{65}$ which is opposite to the case in the $\left[(\mathrm{EtOH})_{2} \mathrm{EtNH}^{+}\right]$based ionic liquids.

With regard to $\left[(\mathrm{EtOH})_{2} \mathrm{EtNH}^{+}\right]\left[\mathrm{NO}_{3}{ }^{-}\right]$, an emf jump at the equivalent point was small, so that the $\mathrm{p} K_{\mathrm{s}}$ value for this PIL could not be estimated quantitatively. Similar quite small jumps in the emf were observed for $\left[\mathrm{C}_{1} \mathrm{hIm}^{+}\right]\left[\mathrm{CH}_{3} \mathrm{COO}^{-}\right]$and $\left[\mathrm{C}_{1} \mathrm{hIm}^{+}\right]\left[\mathrm{HCOO}^{-}\right]$, which can be consistent with large negative $\mathrm{p} K_{\mathrm{s}}$ of about -1.4 for both systems roughly estimated with calorimetric titrations. ${ }^{65}$ Large negative $\mathrm{p} K_{\mathrm{s}}$ means neutral species in the right hand side of the auto-protolysis reaction predominantly exist in equilibrium. Such considerable amount protic ionic liquids. ${ }^{14}$ It should be noted that the gas phase acidity of protonated ethylammonium $\mathrm{EtNH}_{3}{ }^{+}$is remarkably greater than that of nitric acid $\mathrm{HNO}_{3}$, though, as is well known, the former is a conjugate acid of a strong base ethylamine and the latter is a strong acid in the respective aqueous solution. ${ }^{64,66-70}$ As well as Eq. (1), if we select gas phase as the reference state, from the corresponding thermodynamic cycle, Gibbs free energy $\Delta_{\mathrm{r}} G^{\circ}$ (PILs) for the auto-protolysis reaction in $\mathrm{PILs}^{+} \mathrm{HB}^{+}+\mathrm{A}^{-}$ of neutral species formation is evident in the other acetate-based 
$\rightleftharpoons \mathrm{B}+\mathrm{HA}$, can be represented as:

$$
\begin{aligned}
& \Delta_{\mathrm{r}} G^{\circ}(\mathrm{PIL})=\Delta_{\mathrm{r}} G^{\circ}\left(\mathrm{HB}^{+}\right)-\Delta_{\mathrm{r}} G^{\circ}(\mathrm{HA})+\left\{\Delta_{\mathrm{s}} G^{\circ}(\mathrm{B})+\Delta_{\mathrm{s}} G^{\circ}(\mathrm{HA})\right\} \\
&-\left\{\Delta_{\mathrm{s}} G^{\circ}\left(\mathrm{HB}^{+}\right)+\Delta_{\mathrm{s}} G^{\circ}\left(\mathrm{A}^{-}\right)\right\},
\end{aligned}
$$

where $\Delta_{\mathrm{r}} G^{\circ}\left(\mathrm{HB}^{+}\right)$and $\Delta_{\mathrm{r}} G^{\circ}(\mathrm{HA})$ denote gas phase acidity for the respective species (in Gibbs free energy) and $\Delta_{\mathrm{s}} G^{\circ}(\mathrm{X})(\mathrm{X}: \mathrm{B}$, $\mathrm{HA}, \mathrm{HB}^{+}$and $\mathrm{A}^{-}$) stand for solvation Gibbs free energy. Generally, even if $\Delta_{\mathrm{r}} G^{\circ}\left(\mathrm{HB}^{+}\right)-\Delta_{\mathrm{r}} G^{\circ}(\mathrm{HA})$ are negative, $\Delta_{\mathrm{r}} G^{\circ}(\mathrm{PIL})$ is positive owing to much more negative $\Delta_{\mathrm{s}} G^{\circ}\left(\mathrm{HB}^{+}\right)+$ $\Delta_{\mathrm{s}} G^{\circ}\left(\mathrm{A}^{-}\right)$(ion "self-solvation" in ionic liquids) overcoming negative $\Delta_{\mathrm{s}} G^{\circ}(\mathrm{B})+\Delta_{\mathrm{s}} G^{\circ}(\mathrm{HA})$ (neutral molecule solvation). Hence, with regard to $\left[(\mathrm{EtOH})_{2} \mathrm{EtNH}^{+}\right]\left[\mathrm{NO}_{3}{ }^{-}\right]$, it is unlikely that ionic solvation free energy compensates or overcomes the sum of those for gas phase reaction $\Delta_{\mathrm{r}} G^{\circ}\left(\mathrm{HB}^{+}\right)-\Delta_{\mathrm{r}} G^{\circ}(\mathrm{HA})$ and neutral species solvation $\Delta_{\mathrm{s}} G^{\circ}(\mathrm{B})+\Delta_{\mathrm{s}} G^{\circ}$ (HA). This is probably due to the hydrogen bonding interaction operating both in $(\mathrm{EtOH})_{2} \mathrm{EtN} \cdots \mathrm{HNO}_{3}$ and in $(\mathrm{EtOH})_{2} \mathrm{EtNH}^{+} \cdot \mathrm{NO}_{3}{ }^{-} . \quad$ Ab initio calculations support the significant hydrogen bonding interaction of $\mathrm{EtNH}_{2} \cdots \mathrm{HNO}_{3}$ both in gas phase and in a dielectric solution with the PCM (polarlizable continuum model). ${ }^{71,72}$

Hence, the hydrogen bonding between cation-cation and cation-anion plays essential roles in macroscopic properties of the PILs composed of cations with the 2-hydroxyethyl group(s). Large angle neutron ${ }^{63}$ and X-ray ${ }^{71,73}$ scattering experiments with the aid of molecular simulations may provide direct structural evidences at an atomistic level, and are now going on.

\section{Conclusions}

A series of new 2-hydroxyethylammonium based salts were prepared to find 32 protic ionic liquids. Among them, 6 PILs $\left(\left[(\mathrm{EtOH})_{\mathrm{n}} \mathrm{Et}_{(3-\mathrm{n})} \mathrm{NH}^{+}\right]\left[\mathrm{TFS}^{-}\right](n=0-3)\right.$ and $\left[(\mathrm{EtOH})_{2} \mathrm{EtNH}^{+}\right]\left[\mathrm{X}^{-}\right]$ $\left(\mathrm{X}=\mathrm{TFS}\right.$, TFSA and $\left.\mathrm{NO}_{3}\right)$ ) were investigated in terms of the physicochemical properties such as thermal behavior, ionic conductivity, viscosity and density, and the acid-base property of $\mathrm{p} K_{\mathrm{s}}$, to clarify the effect of hydroxyl groups and the anionic nature on the ion-ion interaction and the acid-base property of these new class of PILs.

With regard to $\left[(\mathrm{EtOH})_{\mathrm{n}} \mathrm{Et}_{(3-\mathrm{n})} \mathrm{NH}^{+}\right]\left[\mathrm{TFS}^{-}\right](n=0-3)$, the Walden plots exhibited a good linear relationship. Nevertheless, $V_{\text {inter }}$ of $\left[\left(\mathrm{EtOH}_{\mathrm{n}_{\mathrm{n}}} \mathrm{Et}_{(3-\mathrm{n})} \mathrm{NH}^{+}\right]\left[\mathrm{TFS}^{-}\right](n=0-3)\right.$ decreased with increasing the number of the 2-hydroxyethyl groups. Moreover, the $\mathrm{p} K_{\mathrm{s}}$ became smaller as the increase of the 2-hydroxyethyl groups with a good linear relationship with the least square slope of 1.26 against $\mathrm{p} K_{\mathrm{a}}$ for $(\mathrm{EtOH})_{\mathrm{n}} \mathrm{Et}_{(3-\mathrm{n})} \mathrm{NH}^{+}(n=0-3)$ in the respective aqueous solution. These facts suggest that the hydrogen bonding interactions become more important relative to the Coulombic ones in these PILs when the number of the 2-hydroxyethyl groups increase.

The molar ionic conductivity for $\left[(\mathrm{EtOH})_{2} \mathrm{EtNH}^{+}\right]\left[\mathrm{TFSA}^{-}\right]$ was significantly larger than that for TFS--based PIL, though its viscosity was larger. In addition, the typical potentiometric titration curves for $\left[(\mathrm{EtOH})_{2} \mathrm{EtNH}^{+}\right]\left[\mathrm{TFSA}^{-}\right]$and $\left[(\mathrm{EtOH})_{2} \mathrm{EtNH}^{+}\right]-$ [TFS $\left.{ }^{-}\right]$were successfully obtained. The $\mathrm{p} K_{\mathrm{s}}$ value for $\left[(\mathrm{EtOH})_{2} \mathrm{EtNH}^{+}\right]\left[\mathrm{TFSA}^{-}\right]$is larger than that for TFS ${ }^{-}$-based PIL, suggesting that HTFSA behaves as a stronger acid than HTFS in the respective ILs. This acidity order is consistent with that in the gas phase. On the other hand, in $\left[(\mathrm{EtOH})_{2} \mathrm{EtNH}^{+}\right]\left[\mathrm{NO}_{3}{ }^{-}\right]$, an emf jump was small, suggesting that the comparable hydrogen bonding interaction in strength may operate both in $(\mathrm{EtOH})_{2} \mathrm{EtN} \cdots \mathrm{HNO}_{3}$ and in $(\mathrm{EtOH})_{2} \mathrm{EtNH}^{+} \ldots \mathrm{NO}_{3}{ }^{-}$.

\section{Acknowledgements}

This work has been financially supported by Grant-in-Aids for Scientific Research Nos. 19003963, 19350033, 20350037, 23350033 and 24655142, and for Scientific Research in Priority Area (Ionic Liquids) 20031024 from the MEXT of Japan and Advanced Low Carbon Technology Research and Development Program (ALCA) from Japan Science and Technology Agency (JST). This work was carried out within the Global COE Program of Kyushu University, "Science for Future Molecular Systems".

\section{Supporting Information}

Additional data from details of experiments, physicochemical and acid-base properties of 2-hydroxyethylammonium based ILs, and the relationships between $V_{\text {intra }}$ and $V_{\mathrm{m}}$ and $V_{\text {inter }}$ are given as Supporting Information. This material is available free of charge on the Web at http://www.jsac.or.jp/analsci/.

\section{References}

1. “Ionic Liquids IV', ed. J. F. Brennecke, R. D. Rogers, and K. R. Seddon, 2007, American Chemical Society, Washington, D.C.

2. "Ionic Liquids in Chemical Analysis", ed. M. Koel, 2009, CRC Press, New York.

3. "Ionic Liquids in Sythesis", ed. P. Wasserscheid and T. Welton, 2nd ed., 2007, Vols. 1 and 2, VCH-Wiley, Weinheim.

4. "Electrochemical Aspects of Ionic Liquids", ed. H. Ohno, 2005, Wiley-Interscience, Hoboken.

5. M. Hirao, H. Sugimoto, and H. Ohno, J. Electrochem. Soc., 2000, 147, 4168.

6. M. Yoshizawa, W. Ogihara, and H. Ohno, Electrochem. Solid-State Lett., 2001, 4, E25.

7. H. Ohno and M. Yoshizawa, Solid State Ionics, 2002, $154-155,303$.

8. M. Yoshizawa, W. Xu, and C. A. Angell, J. Am. Chem. Soc., 2003, 125, 15411.

9. J.-P. Belieres and C. A. Angell, J. Phys. Chem. B, 2007, 111, 4926.

10. J. A. Bautista-Martinez, L. Tang, J.-P. Belieres, R. Zeller, C. A. Angell, and C. Friesen, J. Phys. Chem. C, 2009, 113, 12586.

11. C. Thomazeau, H. Olivier-Bourbigou, L. Magna, S. Luts, and B. Gilbert, J. Am. Chem. Soc., 2003, 125, 5264.

12. T. Robert, H. Olivier-Bourbigou, L. Magna, and B. Gilbert, ECS Trans., 2007, 3, 71.

13. T. Robert, L. Magna, H. Olivier-Bourbigou, and B. Gilbert, J. Electrochem. Soc., 2009, 156, F115.

14. K. M. Johansson, E. I. Izgorodina, M. Forsyth, D. R. MacFarlane, and K. R. Seddon, Phys. Chem. Chem. Phys., 2008, 10, 2972.

15. R. Kanzaki, K. Uchida, S. Hara, Y. Umebayashi, S. Ishiguro, and S. Nomura, Chem. Lett., 2007, 36, 684.

16. R. Kanzaki, K. Uchida, X. Song, Y. Umebayashi, and S. Ishiguro, Anal. Sci., 2008, 24, 1347.

17. D. J. Couling, R. J. Bernot, K. M. Docherty, J. K. Dixon, and E. J. Maginn, Green Chem., 2006, 8, 82.

18. P. Nockemann, B. Thjis, K. Driesen, C. R. Janssen, K. V. Hecke, L. V. Meervelt, S. Kossmann, B. Kirchner, and 
K. Binnemans, J. Phys. Chem. B, 2007, 111, 5254.

19. K. Fujita, D. R. MacFarlane, and M. Forsyth, Chem. Commun., 2005, 4804.

20. K. Fujita, M. Forsyth, D. R. MacFarlane, R. W. Reid, and G. D. Elliot, Biotechnol. Bioeng., 2006, 94, 1209.

21. K. Fujita, D. R. MacFarlane, M. Forsyth, M. YoshizawaFujita, K. Murata, N. Nakamura, and H. Ohno, Biomacromolecules, 2007, 8, 2080.

22. K. Fujita and H. Ohno, Biopolymers, 2010, 93, 1093.

23. E. R. Cooper, C. D. Andrews, P. S. Wheatley, P. B. Webb, P. Wormald, and R. E. Morris, Nature, 2004, 430, 1012.

24. J. Gorke, F. Srienc, and R. Kazlauskas, Biotechnol. Bioprocess Eng., 2010, 15, 40.

25. X. Yuan, S. Zhang, J. Liu, and X. Lu, Fluid Phase Equilib., 2007, 257, 195.

26. L. M. Galan Sanchez, G. W. Meindersma, and A. B. de Haan, Trans.-ChemE, Part A, Chem. Eng. Res. Des., 2007, 85,31 .

27. D. Camper, J. E. Bara, D. L. Gin, and R. D. Noble, Ind. Eng. Chem. Res., 2008, 47, 8496.

28. K. A. Kurnia, F. Harris, C. D. Wilfred, M. I. Abdul Mutalib, and T. Murugesan, J. Chem. Thermodyn., 2009, 41, 1069.

29. S. Mattedi, P. J. Carvalho, J. A. P. Coutinho, V. H. Alvarez, and M. Iglesias, J. Supercrit. Fluids, 2011, 56, 224.

30. A. Pinkert, K. N. Marsh, S. Pang, and M. P. Staiger, Chem. Rev., 2009, 109, 6712.

31. A. Pinkert, K. N. Marsh, and S. Pang, Ind. Eng. Chem. Res., 2010, 49, 11809.

32. H.-M. Choi and I. Kwon, Ind. Eng. Chem. Res., 2011, 50, 2452.

33. S. S. Palimkar, S. A. Siddiqui, T. Daniel, J. Lahoti, and K. V. Srinivasan, J. Org. Chem., 2003, 68, 9371.

34. D. Fang, Q.-R. Shi, J. Cheng, K. Gong, and Z.-L. Liu, Appl. Catal., A, 2008, 345, 158.

35. Y. Wang, D. Jiang, and L. Dai, Catal. Commun., 2008, 9 , 2475.

36. Y. Zhao, J. Long, F. Deng, X. Liu, Z. Li, C. Xia, and J. Peng, Catal. Commun., 2009, 10, 732.

37. J. Yang, H. Zhou, X. Lu, and Y. Yuan, Catal. Commun., 2010, 11, 1200.

38. N. Bicak, J. Mol. Liq., 2005, 116, 15.

39. T. L. Greaves, A. Weerawardena, C. Fong, I. Krodkiewska, and C. J. Drummond, J. Phys. Chem. B, 2006, 110, 22479.

40. I. Cota, R. Gonzalez-Olmos, M. Iglesias, and F. Medina, $J$. Phys. Chem. B, 2007, 111, 12468.

41. X. L. Yuan, S. J. Zhang, and X. M. Lu, J. Chem. Eng. Data, 2007, 52, 596.

42. T. L. Greaves, A. Weerawardena, I. Krodkiewska, and C. J. Drummond, J. Phys. Chem. B, 2008, 112, 896.

43. K. A. Kurnia, C. D. Wilfred, and T. Murugesan, J. Chem. Thermodyn., 2009, 41, 517.

44. G. L. Burrell, I. M. Burgar, F. Separovic, and N. F. Dunlop, Phys. Chem. Chem. Phys., 2010, 12, 1571.

45. V. H. Alvarez, N. Dosil, R. Gonzalez-Cabaleiro, S. Mattedi, M. Martin-Pastor, M. Iglesias, and J. M. Navaza, J. Chem. Eng. Data, 2010, 55, 625.

46. A. Pinkert, K. L. Ang, K. N. Marsh, and S. Pang, Phys. Chem. Chem. Phys., 2011, 13, 5136.

47. M. Yoshizawa-Fujita, Y. Kousa, K. Kidena, A. Ohira, Y. Takeoka, and M. Rikukawa, Phys. Chem. Chem. Phys.,
2011, 13, 13427.

48. K. A. Kurnia, M. I. Abdul Mutalib, T. Murugesan, and B. Ariwahjoedi, J. Solution Chem., 2011, 40, 818.

49. K. Kawai, K. Kaneko, and T. Yonezawa, Langmuir, 2011, 27,7353 .

50. K. A. Kurnia, M. M. Taib, M. I. Abdul Mutalib, and T. Murugesan, J. Mol. Liq., 2011, 159, 211.

51. T.-Y. Wu, S.-G. Su, K.-F. Lin, Y.-C. Lin, H. P. Wang, M.-W. Lin, S.-T. Gung, and I.-W. Sun, Electrochim. Acta, 2011, 56,7278 .

52. Y. Fukaya, Y. Iizuka, K. Sekikawa, and H. Ohno, Green Chem., 2007, 9, 1155.

53. M. Khodadadi-Moghaddam, A. Habibi-Yangjeh, and M. R. Gholami, Appl. Catal., A, 2008, 341, 58.

54. M. Khodadadi-Moghaddam, A. Habibi-Yangjeh, and M. R. Gholami, Monatsh. Chem., 2009, 140, 329.

55. S. Zhang, X. Qi, X. Ma, L. Lu, and Y. Deng, J. Phys. Chem. $B, 2010,114,3912$.

56. P. Walden, Physik Chem., 1906, 55, 207 and 246.

57. W. Xu, E. I. Cooper, and C. A. Angell, J. Phys. Chem. B, 2003, 107, 6170 .

58. U. L. Bernard, E. I. Izgorodina, and D. R. MacFarlane, J. Phys. Chem. C, 2010, 114, 20472.

59. J. Stoimenovski, E. I. Izgorodina, and D. R. MacFarlane, Phys. Chem. Chem. Phys., 2010, 12, 10341.

60. K. Yoshida, M. Tsuchiya, N. Tachikawa, K. Dokko, and M. Watanabe, J. Phys. Chem. C, 2011, 115, 18384.

61. K. Fujii, R. Kanzaki, T. Takamuku, Y. Kameda, S. Kohara, M. Kanakubo, M. Shibayama, S. Ishiguro, and Y Umebayashi, J. Chem. Phys., to be published.

62. S. Seki, T. Kobayashi, Y. Kobayashi, K. Takei, H. Miyashiro, K. Hayamizu, S. Tsuzuki, T. Mitsugi, and Y. Umebayashi, J. Mol. Liq., 2010, 152, 9.

63. R. Hayes, S. Imberti, G. G. Warr, and R. Atkin, Phys. Chem. Chem. Phys., 2011, 13, 3237.

64. I. A. Koppel, R. W. Taft, F. Anvia, S.-Z. Zhu, L.-Q. Hu, K.-S. Sung, D. D. DesMarteau, L. M. Yagupolskii, Y. L. Yagupolskii, V. M. Vlasov, R. Notario, and P.-C. Maria, J. Am. Chem. Soc., 1994, 116, 3047.

65. R. Kanzaki, X. Song, S. Hara, Y. Umebayashi, and S. Ishiguro, Anal. Chem., submitted.

66. J. I. Brauman and L. K. Blair, J. Am. Chem. Soc., 1969, 91, 2126.

67. J. I. Brauman and L. K. Blair, J. Am. Chem. Soc., 1971, 93, 3911.

68. J. I. Brauman and L. K. Blair, J. Am. Chem. Soc., 1971, 93, 3914.

69. M. Meot-Ner and L. W. Sieck, J. Am. Chem. Soc., 1991, $113,4448$.

70. E. P. L. Hunter and S. G. Lias, J. Phys. Chem. Ref. Data, 1998, 27, 413.

71. X. Song, H. Hamano, B. Minofar, R. Kanzaki, K. Fujii, Y. Kameda, S. Kohara, M. Watanabe, S. Ishiguro, and Y. Umebayashi, J. Phys. Chem. B, 2012, 116, 2801.

72. X. Song, R. Kanzaki, and Y. Umebayashi, Kyushu University Global-COE Program Science for Future Molecular Systems Journal, 2012, 5, to be published.

73. Y. Umebayashi, W. Chung, T. Mitsugi, S. Fukuda, M. Takeuchi, K. Fujii, T. Takamuku, R. Kanzaki, and S. Ishiguro, J. Comput. Chem., Jpn., 2008, 7, 125. 